Teologia i Moralność, Volumen 15(2020), numer 1(27)

doi: 10.14746/tim.2020.27.1.01

ORCID: 0000-0003-4678-726X

\author{
ANTONI BARTOSZEK \\ University of Silesia in Katowice \\ Faculty of Theology
}

\title{
From chastity to human ecology contribution to the ethical argumenation
}

\section{Introduction - chastity accused}

In the Christian tradition the notions 'purity' and 'virtue' have always been very important. When that were connected, the term 'chastity' appeared. It was used to differentiate between what was sinful and what was not. What was 'chaste' (pure, clean) was good; what was 'unchaste' (impure, unclean) was bad and sinful. The ideals were 'a chaste boy,' 'a chaste girl,' 'a chaste marriage;' any way of being 'unchaste' was improper.

This notion of chastity brought some difficulties. Firstly, the terms 'pure' and 'impure' (chaste / unchaste) have not always preserved the same meaning. Their semantic meaning depended on the more fundamental, anthropological foundation. In Manicheism and all its later modifications 'chastity' (purity, cleanness) was understood as total sexual abstinence, while any sexual activity was considered impure, unclean (unchaste).

Secondly, while pointing to the fact that 'sexual purity' was deeply rooted in the Scripture, possible misunderstandings were highlighted. People were warned against identifying the virtue of chastity with the Old Testament notion of ritual cleanness. And it is really easy to make this mistake, the more so that according to Mosaic Law ritual uncleanness was particularly often connected with human sexuality ${ }^{1}$. At the same time it was reminded that the Bib-

\footnotetext{
${ }^{1}$ The notions of cultic 'cleanness' and 'uncleanness' appear in the whole Bible, particularly in the Old Testament. They are explained in detail in Leviticus, chapters 11 to 16, in the "Law of cleanness'. The whole chapter 15, with the subtitle "Sexual Uncleanness," presents the ways in which various aspects of sexuality caused cultic uncleanness. In the most common translation of the Bible used in Poland, The Millenium Bible, the following footnote is added to this chapter: "Anything
} 
lical message contains a much broader understanding of 'cleanness' (purity). For example, it was justly indicated that one of the beatitudes reads: "Blessed are the pure in heart: they shall see God"2 (Mt 5:8), and Jesus said: "You are clean already, by means of the word that I have spoken to you" (Jn 15:3). It was highlighted that 'cleanness' generally means 'sinlessness'. And 'uncleanness' is not only connected with sexual sins but pertains to various other forms of moral impropriety, in accordance with the words of Jesus: "For it is from within, from the heart, that evil intentions emerge: fornication, theft, murder, adultery, avarice, malice, deceit, indecency, envy, slander, pride, folly. All these evil things come from within and make a person unclean" (Mk 7:21-23).

Thirdly, though in Polish the word 'clean' has very positive connotations, the Latin word castitas (i.e. cleanness, purity) comes from the verb castigare (meaning 'bridle,' 'restrain') and is translated as 'control'. This term stresses the negative aspect of cleanness (chastity), namely the necessity to control the sexual urge, just like one puts a bridle on a horse or regulates a rushing stream (Marcol 1998, 96). While presenting the essence of cleanness (in its negative aspect) A. Marcol referred to St. Thomas Aquinas (Summa theologica II-II, q. 151, a. 1).

In spite of those difficulties, the value of cleanness has always been emphasized (and is nowadays), with a certain clarification: that while speaking about cleanness we neither support Manicheism, nor narrow cleanness to the sexual sphere, nor focus on its negative aspect. Such an approach is absolutely correct. However, all those clarifications do not change the fact that both crucial terms - 'virtue' and 'cleanness' - are concepts that are often misunderstood nowadays, or even seem to have a negative meaning. Both these notions are associated with the Christian religion and - though this view is completely wrong - show the negative side of religiousness.

We face two possibilities in the context of accusing the 'virtue of cleanness.' On one hand we may try to rehabilitate both virtue and cleanness (chastity). It was M. Scheler who appealed for 'rehabilitation of chastity,' and then K. Wojtyla followed him. K. Wojtyła while presenting 'rehabilitation of chastity' in Love and Responsibility, refers to M. Scheler's The Rehabilitation of Virtue (Wojtyla 1993, 143). It is enough to show the Latin etymology of the word 'virtue' (virtus) and explain that it pertains to moral 'valour'. Wojtyla, following Aristotle and Thomas Aquinas, spoke about virtue as a capacity

\footnotetext{
connected with sexual life caused ritual uncleanness;" and the footnote to the same chapter in the Poznan Bible runs as follows: "Chapter 15 does not deal only with the unhealthy symptoms of sexuality. . . but with all natural secretions of sexual organs, both male and female. It is so because in ancient times everything that pertained to fertility and procreation was perceived as mysterious and somehow holy."

${ }^{2}$ Passages from the Bible are quoted according to The New Jerusalem Bible. https://www. catholic.org/bible/books_bible.php [AJ].
} 
(Wojtyla 1993, 169). One may also demonstrate that 'cleanness' brings positive associations everywhere outside the context of sexuality: it is a value expected and it is not a concept belonging primarily to the sphere of religion. Due to a well-conducted rehabilitation of "the virtue of chastity" this notion regains its radiance and may be (in the social and ecclesial sphere) a carrier of a very positive message (Wojtyla 1993, 143-173).

On the other hand, the notion of 'sexual cleanness' or chastity, may be substituted by new terminology, and thus the terms like 'sexual integration' or 'human ecology' may be used instead of 'chastity'. The first of these is already well-settled in Christian sexual ethics. The latter is still new and a question arises whether such a substitution is possible at all. The following analyses will be an attempt to answer the question whether the term 'sexual cleanness,' chastity, may be substituted by 'human ecology'. And if the answer is 'yes,' is this process of substitution really unconditional? Wouldn't it be a kind of a narrowing, a reduction of the message that comes from the notion of chastity? Aren't these semantic attempts some kind of superficial surrender to fashionable social tendencies?

In order to be able to answer all these questions we first need to focus on the concept of 'sexual integration,' ponder upon its essence and try to figure out why it has become particularly valuable in Christian sexual ethics.

\section{Sexual integration is the anthropological foundation of man}

The holistic view of man, who (to be fully understood) cannot be reduced to a single aspect, is the key to understanding what sexual integration is. We need to look at man in a holistic way and see the basic unity and identity on one hand and the complexity with its bio-physical, psycho-emotional, sociocultural and spiritually-religious dimensions, on the other. Eventually, one may say that man is a physio-psycho-spiritual unity living and functioning in a particular social environment ${ }^{3}$. Human sexuality reveals itself in these dimensions too, as it is not an addition to being human but it is connected with all the spheres of humanity. In the biological dimension sexuality is expressed (among others) in a particular genetic and hormonal structure, and also in the primary, secondary and tertiary sex characteristics. In the psychological di-

${ }^{3}$ If in Christian tradition it is said that man is bodily and spiritual unity, it is done to show that man is a combination of the empirical and non-empirical elements. The tripartite, distinguishing the ,psychic" aspect, helps to enter into a dialogue with modern anthropological concepts that emphasize the human psyche so strongly. At the same time, the separation of the mental and spiritual dimensions shows the irreducibility of the human spirit and spirituality to the psyche, which is often the case in some contemporary anthropological visions. 
mension sexuality is expressed in the emotional sphere, in the feelings of falling in love, the joy of pleasure, the need for intimacy and tenderness, and also in various wounds and defence mechanisms. Also the socio-cultural perception of sex (gender), one that is so different in various times and places, reveals itself in human relationships. And finally, in the spiritual dimension, sexuality reveals itself in its reference to personal love understood as an attitude of responsibility for oneself and another person, rooted in intellective recognition and moral decisions.

Full integration, full harmony in all human dimensions of sexuality: this is what is covered by the concept of 'chastity' in the Christian tradition. It is worthwhile to remind the definition of chastity from the Catechism: "Chastity means the successful integration of sexuality within the person and thus the inner unity of man in his bodily and spiritual being." (Catechism of the Catholic Church 1994, no. 2337) The inner unity of sexuality known as 'sexual integrity' has already been the subject for numerous scientific researches. The works of Fr. Józef Augustyn in this field are particularly well known in the Polish environment, including his fundamental publication entitled Sexual Integration. J. Augustyn derived the notion 'sexual integration' from the category of 'integration' developed by W.G. Allport. In J. Augustyn's view, “Sexual integration consists in uniting the genital, emotional and spiritual spheres in one experience of love" (Augustyn 195, 72). It would be worthwhile to emphasize that the already mentioned book by K. Wojtyła, Love and Responsibility, contains clear references to integrity (Wojtyła 1993, 307). It is precisely this concept that has become essential to understand the truth about human sexuality in its fullness and depth. First of all, this concept points to the anthropological reality from which specific moral standards for the sexual sphere can be derived. It is particularly important not to treat integration itself as a purpose of its own. Similarly, chastity should not be treated as the ultimate aim of human activity in the area of sexuality. Both chastity and sexual integration are anthropological carriers. The aim is love in its deepest, personal meaning. Integrated sexuality makes it possible to experience love in all its dimensions: physical, psychological and spiritual. Love understood in this way is the aim and sense of human existence and human sexuality.

There arises a question about where to place sexual activity in this anthropological vision. Sexual activity is based on personal love expressed in a full, total and irrevocable, complementary with respect to sex, unity of life of two persons - in other words in marriage. Thus, sexual activity constitutes an important element of marriage, and marriage only. Outside of marriage it leads to the disintegration of a person. Such a vision has always been and still is guarded by the Commandment "You shall not commit adultery" (Ex 20:14), confirmed and deepened by Jesus in the Sermon on the Mount (Mt 5:27n). 
"Adultery is a falsification of that sign which does not have its 'legality' so much as its simple interior truth in marriage - that is, in the cohabitation of the man and the woman who have become a married couple" (John Paul II 1986, 95). And sexual activity in marriage is open to procreation by its very nature. This is the vision of sexuality guarded by the Magisterium of the Church. It is included in the encyclical letter Humanae vitae, which teaches about the unitive and procreative significance of the conjugal act, and objects to any sexual activity that is not open to life, as well as in the instructions Donum vitae and Dignitas personae, which object to procreation without conjugal act.

Thus, sexual integration is made possible due to the discovery of the fundamental anthropological truth; in other words, due to finding the answer to the question "Who a human person is?" It was our Lord Jesus who appealed for reaching back to the fundamental truth about people, sexuality and marriage. In his discussion with the Pharisees he left aside various false ideas that were the result of the original sin, rushed through liberating tendencies included in the Mosaic Law (first of all dealing with the issue of divorce) and showed what marriage was like at 'the beginning,' during creation (cf. Mt 19:1-9). This methodology of referring 'to the beginning' was reminded by John Paul II in his theology of the body (John Paul II 1986, 7-86). The reference 'to the beginning' is not a longing for the lost paradise neither is it a desire to rebuilt the paradise. After the Fall no man can return to the garden of Eden; now people head for "the Father's house" (Jn 14:2), which ultimately (in the general, even cosmic dimension) will become "a new heaven and a new earth" (Rev 21:1). The reference 'to the beginning' is to serve one fundamental purpose: to understand the primary plan of God for humanity and to comprehend human nature which was created by God and which reveals itself in the fundamental structure of a person as well as in the natural law. John Paul II offers the following interpretation of the words of Jesus in which he tells his interlocutors that they should refer 'to the beginning,' i.e. the Creation: "Jesus Christ's words confirm the eternal law formulated and set up by God from 'the beginning' as the creation of man. It might also seem that the Master, confirming this original law of the Creator, did nothing but establish exclusively his own normative meaning, referring to the authority itself of the first Legislator. However, that significant expression 'from the beginning,' repeated twice, clearly induced his interlocutors to reflect on the way in which man was formed in the mystery of creation, precisely as "male and female," in order to understand correctly the normative sense of the words of Genesis." (John Paul II 1986, 8). The reference 'to the beginning' - in accordance with the words of Jesus - is a help in discovering the truth about marriage.

Finally, one should add that the reference 'to the beginning' presents the fundamental source of human existence which is a kind of 'house/home' 
(oikos) which man left. Looking at the truth about humanity in the perspective of creation, i.e. grasping this truth in the perspective of the primary house (oikos) of people, constitutes the basic dimension of what we call today 'human ecology.' Since it is possible to create a clear picture of human ecology on the basis of the work of creation, it would be worthwhile to try to figure out to what extend it can be a convincing way of presenting the truth (anthropological and ethical) about human sexuality.

\section{Human ecology as new argumentation in the sphere of sexuality}

The term 'ecology' comes from two Greek words: oikos - house and logos - word, and thus its etymological meaning is 'study of house/home.' From the point of view of science, ecology is a study of organisms in 'their house or home,' in their home environment. This simple definition of contemporary ecology, which was formulated by C.A. Ville, is referred to in the article of M. Wyrostkiewicz (Wyrostkiewicz 2016, 60). The 'house/home' here is the basic natural environment of a given organism. And man is responsible for this environment - such is the design of God. John Paul II writes about it in his Encyclical Letter Evangelium vitae: "As one called to till and look after the garden of the world (cf. Gen 2:15), man has a specific responsibility towards the environment in which he lives, towards the creation which God has put at the service of his personal dignity, of his life, not only for the present but also for future generations. It is the ecological question - ranging from the preservation of the natural habitats of the different species of animals and of other forms of life to 'human ecology' properly speaking" (EV, no. 42). John Paul II treats the work of creation as his starting point and speaks about the protection of the natural environment but eventually he speaks about 'human ecology,' i.e. about the care for the environment not for its own sake but because of humans beings and their personal dignity.

The term 'human ecology' may be also used in a slightly different meaning. It may be understood not so much as the protection of the natural environment because of man, but rather as the protection of one's own nature, i.e. of the personal structure of a human person. While speaking about the ecology of man Benedict XVI said: "Man too has a nature that he must respect and that he cannot manipulate at will" (Benedict XVI 2011). And it is this respect for one's personal nature that is described not so much as the 'ecology of man' but as 'human ecology.' This is also what Pope Francis shows: "Human ecology also implies another profound reality: the relationship between human life and the moral law, which is inscribed in our nature and is necessary for the creation of a more dignified environment" (LS, no. 155). Here we can clearly see 
that in the concept of 'human ecology' the anthropological aspect is closely connected with the ethical one, and this unity results in deriving ethical standards and decrees from the personal structure of man.

M. Wyrostkiewicz follows a similar path and states that human ecology takes man into account, seeing him as an element of the natural environment on one hand and as a creature that transcends the natural environment on the other (Cf. Wyrostkiewicz 2016, 64). Thus, we deal here with a fundamental anthropological truth that man is a part of the natural environment but transcends this environment due to his spirituality. This statement is derived from the truth about the work of creation. So we have here a house/home (oikos), understood as a source. Next, M. Wyrostkiewicz states that the aim of the human ecology is "to develop a vision of the world ordered according to the natural (i.e. grafted by the Creator) laws, and also to abstract standards which make preservation of this order possible" (Wyrostkiewicz 2016, 64). Let us add that the aim is not only (and not primarily) to understand the laws of nature, but also (in fact primarily) to understand the standards included in the personal structure of man, i.e. in what we generally describe as natural law.

To sum up, we may claim that the ecology of man is the care for the natural environment because of man's dignity, and human ecology is the care for the nature of a human person understood not in biological terms but as a complete physio-psycho-spiritual structure. Ecology of man might be labelled 'exterior' because it emphasises what is outside of a person, and human ecology might by labelled 'interior' because it emphasizes the inner structure of a person.

The way in which the term 'human ecology' was used in the Encyclical Letter Centesimus annus is very interesting. The Pope writes: "The first and fundamental structure for 'human ecology' is the family, in which man receives his first formative ideas about truth and goodness, and learns what it means to love and to be loved, and thus what it actually means to be a person. Here we mean the family founded on marriage, in which the mutual gift of self by husband and wife creates an environment in which children can be born and develop their potentialities, become aware of their dignity and prepare to face their unique and individual destiny" (CA, no. 39). On one hand we see here the 'external ecology' because John Paul II points to the family as the fundamental environment of man. But on the other hand, the environment which the pope speaks about is a personal environment, one that is deeply rooted in the structure of a human person. So ultimately what is described is the "internal ecology' and probably this is why we have here the term "human ecology" and not 'ecology of man.' Thus, if family is the first and fundamental structure of human ecology, also marital relations constitute an element of human ecology. Similarly, the very 'being a man' or 'being a woman' constitutes an element of human ecology in its anthropologically-ethical interrelation. And here we 
are just one step away from stating that sexual integration, the physio-psychospiritual unity of sexuality, which was discussed earlier in this text, constitutes the fundamental dimension of human ecology.

Of course, human ecology, being the starting point for deciphering the moral law inscribed in the nature of man, is a notion broader that sexual integration. Human ecology deals with all human behaviours, sexual integration pertains to behaviours in the sphere of sexuality (in a broad sense). When we put together human ecology and the deliberations about sexual integration presented above, two fundamental principles concerning human ecology in the sphere of sexuality may be formulated. The first of them might run as follows: sexual activity is ecological only within marriage, thus only sexual abstinence is ecological before and out of marriage. The second principle might be: sexual activity is ecological only if it is open to life, and conversely, the only ecological openness to life is the one connected with the sexual act. Consequently, all methods of natural family planning, ${ }^{4}$ as well as NaProTechnology (Kopera, 2010, 89-93; Gadzinowski 2017, 134) are ecological.

Any activity breaking these rules is in conflict with human ecology. Any sexual activity before or out of marriage breaks the first principle of human ecology. Thus, premarital sex, adultery, homosexual acts and degenerative behaviours such as pornography, prostitution, and paedophilia, are all nonecological. And the second principle of human ecology in the sphere of human sexuality is broken by any activity which artificially separates marital act from openness to life, as well as by any acts aimed at transmission of life outside of marital act. Thus contraception and all techniques of artificial procreation are all nonecological. The Magisterium of the Church has already defined some of the above-mentioned activities as offences against human ecology. In the Encyclical Letter Caritas in Veritate Benedict XVI wrote: "If there is a lack of respect for the right to life and to a natural death, if human conception, gestation and birth are made artificial, if human embryos are sacrificed to research, the conscience of society ends up losing the concept of human ecology and, along with it, that of environmental ecology" (Benedict XVI 2009, 51).

Of course, at this moment each of the activities mentioned above should be analysed separately in order to prove their being nonecological. Let us present as an example arguments supporting the ecological character of sexual abstinence before getting married and the nonecological character of the opposite behaviour. Scientific research has investigated the effectiveness of particular

${ }^{4} \mathrm{~W}$. Fijałkowski claimed that nothing is more rooted in ecology than observing the natural law which governs human fertility, and this is precisely the basic assumption of natural family planning (Fijałkowski 2001, 8). "A woman's use of methods based on her own fertility awareness-ecological and free of side effects-brings benefits reaching far beyond the prevention of unplanned pregnancy" (Ekologia prokreacji 2016, s. 51). 
prevention programmes in the area of risky teenager behaviour. One of the factors in the assessment of their effectiveness is the HIV infection rate and the number of teenage pregnancies. It has been proved that prevention programmes based primarily on the so called primary change of behaviour, i.e. promotion of the attitude supporting sexual abstinence before marriage and fidelity to one partner, are much more effective than programmes functioning on the basis of the so-called secondary change of behaviour, which primarily promote contraception. Programmes of the first type resulted in a decrease of the number of HIV infections and teenage pregnancies, however, programmes of the second type brought a rise in both. ${ }^{5}$ Thus, we have a clear empirical proof of the ecological character of chastity. Support for the primary change of behaviour is a health-promoting strategy so it may be characterized as an ecological activity which can be promoted by pedagogy, psychology and medicine.

\section{Christological character of human ecology (also in the sexual sphere)}

Proving that particular sexual behaviours are either ecological or nonecological may become a new way of argumentation in sexual ethics. Particularly the young generation like to use the language of ecology and know how to do it. And they use this language to describe issues that did not need it earlier. For example the attitude of being frugal, which was once encouraged by the virtue of temperance, one of the cardinal virtues, is now often called an ecological attitude. On the other hand, the maximum care not to waste food which was once called 'caring for the gifts of God' and 'an act of solidarity with the starving,' today is described as ecological activity. Of course it is all in accord with the message of the Encyclical Letter Laudato si by Pope Francis and its concept of integral ecology. It seems that the change in the vocabulary may contribute to a better understanding of the Christian message in the area of human sexuality. However, one should remember in this place that it does not suffice to prove only the ecological or nonecological character of particular activities, just like all ecological activity of man does not suffice on its own. This issue needs a deeper theological investigation, but we should add immediately, that the very reference to the truth about the creation of the world and of man (what ecology does and what is generally legitimate) eventually turns out to be insufficient. It is

\footnotetext{
${ }^{5}$ The analysis of the effectiveness of particular prevention programmes in the area of risky teenage behaviour was the subject of research of S. Grzelak (among others). The analysis of the effectiveness of e.g. British prevention programmes proved the failure of promoting secondary change in behaviour, and the analysis of programmes based on promotion of primary change in behaviour which had been implemented for some time in the USA, proved their high effectiveness (Grzelak 2006, 96-125).
} 
so because this reference does not take into account the Fall and its consequences, which are visible in the life of individuals and in the life of whole societies.

The truth is that human sin is the source of any possible disintegration (sexual disintegration included). It is described first of all in the Book of Genesis. It presents brilliantly how the Fall resulted in the appearance of shame, the obvious symptom of internal disintegration in the sexual sphere (cf. Gen 3:7). According to Genesis the first sin resulted also in relational disintegration: "Your yearning will be for your husband, and he will dominate you" (Gen 3:16). The First Letter of John on the other hand tells us about disordered desires which are the result of the original sin. It enumerates the disordered bodily desires, disordered desires of the eyes, and pride in possession as the fundamental ones. It was B. Jurczyk who wrote about the necessity of referring to the truth of sin while speaking about the ecological issue: "It is necessary to reach for the 'deep sources' of a given situation while touching the issue of ecology. These sources point to the misterium iniquitatis in which a human heart has been entangled since the Fall. The ecological issue constitutes the new, civilizational face of the mystery of evil and sin in which a human heart is entangled. . . The so-called ecological sin is committed first of all by particular persons who submit to the sin of lust, pride and egoism (Cf. 1 J 2:16)" (Jurczyk 2016, 26). Those who speak about sin within the realm of ecology often indicate that it consists in upsetting the order of creation and Creator. Such a thought is brought forward by A. Szafulski who follows P. Bortkiewicz in this respect (Szafulski 2016, 53). And the core of many improper behaviours in the sexual sphere (in a broad sense) is that man wants to take the place of God. One very clear example is the issue of contraception, which is first of all a sin against the First Commandment (Bartoszek 2014, 235n).

Of course, in order to overcome sexual disintegration in an individual, in interpersonal relations and in the whole society, i.e. to build true human ecology, also in the sexual sphere, we need to undertake activities of psychological and educational nature. However, eventually

they always prove to be insufficient if they do not take into consideration the reality of sin and the possibility of being freed from both sin and its effects due to Jesus Christ, the Saviour of man and the world. John Paul II, while referring 'to the beginning,' i.e. to the work of creation, shows that already after the first $\sin$ - thanks to the so-called proto-evangelium (Gen 3:15) - man begins to live in 'the theological perspective of the redemption.' (John Paul II 1986, s. 14). Jesus Christ, through his work of redemption, brings the ultimate and deepest liberation from any entanglement in evil and sin which bring disintegration and even destroy human ecology. In the context of theology J. Brusiło writes about the connection between the tree from Eden, the wood of Noah's Ark and the wood of the Cross (Brusiło 2016, 42). 
Thus human ecology needs to discover the meaning of the person of Jesus. Only if a person is united with Jesus, establishing of perfect harmony and full integration (sexual integration included) in a person, and ultimately building the deepest human integration, becomes possible. Living 'in Christ' (cf. Phil 1:21) through faith, due to the power of Baptism, makes it possible for a person to remain in the environment which is most appropriate for them. It is truly remaining 'in one's house' (oikos) and it expresses the fundamental human ecology. The work of redemption accomplished by Jesus brings as its fundamental fruit peace, which is expressed also in full sexual integration (among many other dimensions). Each sin brings anxiety and is the source if disintegration. This is why reconciliation in the Sacrament of Penance, which always means coming 'back home' (oikos), is so important. Thus, going to confession, which restores the state of baptismal innocence in a person, may be recognized as ecological behaviour. In this context it would be worthwhile to refer to the address of Cardinal Mauro Piacenza at the beginning of a course organized by the Apostolic Penitentiary: "The Sacrament of Reconciliation is the only ecology of the soul, because it not only leads to forgiveness and abolition of our sins, but it also renews the soul and recreates in it the baptismal innocence" (Piacenza 2019).

The grace of Jesus makes it possible for a person to reach the ultimate aim of human existence: full unity with Christ in "the Father's house." And, in the universal dimension, the unity with Christ leads to the creation of "a new heaven and a new earth" which is the ultimate establishment of a fully integrated environment, including human ecology. Saint Paul writes about it in the following way: "for the whole creation is waiting with eagerness for the children of God to be revealed. It was not for its own purposes that creation had frustration imposed on it, but for the purposes of him who imposed it - with the intention that the whole creation itself might be freed from its slavery to corruption and brought into the same glorious freedom as the children of God. We are well aware that the whole creation, until this time, has been groaning in labour pains" (Rom 8:19-22). The ultimate salvation of man emerges here as the ultimate salvation of all creation. It is important for the issue of ecology, human ecology included (also the one in the sphere of sexuality)/ which is rooted in the theology of creation, to be also deeply permeated with the Christological, soteriological and eschatological message. "The New Testament does not only tell us of the earthly Jesus and his tangible and loving relationship with the world. It also shows him risen and glorious, present throughout creation by his universal Lordship: 'For in him all the fullness of God was pleased to dwell, and through him to reconcile to himself all things, whether on earth or in heaven, making peace by the blood of his cross' (Col 1:19-20). This leads us to direct our gaze to the end of time, when the Son will de- 
liver all things to the Father, so that 'God may be everything to every one' (1 Cor 15:28)" (LS, no. 100).

The theological thread, which we bring up here, protects us against trivialisation of human sexuality, which might be the case when we associate it with human ecology. It is disputable whether 'chastity' (cleanness, purity) might be substituted by 'sexual integration' or 'human ecology;' terms like 'unchastity' (uncleanness, impurity), 'disintegration,' or 'nonecological activity' might be used to describe improper behaviours in the sphere of sexuality. However, in no case should the truth about human sinfulness, including sinfulness in the sexual sphere be diminished. One should remember though, that realizing the truth about our sinfulness is not equal to pessimism, it is just realism in the recognition of human condition. And relating human sin to Jesus' work of redemption brings hope that integration, sexual integration included, will return and be firmly established, and it also brings hope that the deepest human ecology in the individual, interpersonal and global dimensions will be developed.

translated by Agata Jankowiak

\section{OD CZYSTOŚCI DO EKOLOGII LUDZKIEJ. WKŁAD DO ARGUMENTACJI ETYCZNEJ}

\section{Streszczenie}

Kategoria „,czystości” w sensie moralnym, a szczególnie w obszarze ludzkiej seksualności jest dziś postrzegana ambiwalentnie. $Z$ jednej strony stale posiada swoją wartość antropologiczno-etyczną, z drugiej jednak strony jest coraz mniej nierozumiana, a nawet oskarżana o nieaktualność i nienaukowość. Niniejszy artykuł stanowi próbę wykazania, że to co dotychczas kryło się pod pojęciem „czystości seksualnej” można - pod pewnymi warunkami - zastąpić kategorią „ekologii ludzkiej”. Mostem łączącym „czystość seksualną” z „ekologią ludzką" może być (tego starają się dowieść niniejsze analizy) pojęcie „integracji seksualnej”. Prowadzone tu rozważania wykazują adekwatność terminu „ekologii ludzkiej” w obszarze argumentacji etycznej, dotyczącej ludzkiej płciowości. Jednak termin ten zachowa swoją głębię (i nie będzie oskarżony o powierzchowność) tylko wówczas, gdy będzie zawierał wymiar teologiczny, nie tylko protologiczny, ale także chrystologiczny oraz eschatologiczny.

Slowa kluczowe: ekologia ludzka; seksualność; integracja; czystość

Keywords: human ecology; sexuality; integration; chastity; cleanness; purity 


\section{LIST OF ABBREVIATORS}

CA - John Paul II, Encyclical Letter Centesimus Annus.

CCC - Catechizm of the Catholic Church.

CV - Benedict XVI, Encyclical Letter Caritas in Veritate, on Integral Human Development in Charity and Truth.

DP - Congregation for the Doctrine of the Faith, Dignitas Personae: Instruction on Certain Bioethical Questions.

DV - Congregation for the Doctrine of the Faith, Donum Vitae: Instruction on Respect for Human Life in Its Origin and on the Dignity of Procreation.

EV - John Paul II, Encyclical Letter Evangelium Vitae, on the Value and Inviolability of Human Life.

HV - Paul VI, Encyclical Letter Humanae vitae, on the Regulation of Birth.

LS - Francis, Encyclical Letter Laudato Si on Care for our Common Home.

\section{BIBLIOGRAPHY}

\section{Magisterium of the Church}

Benedict XVI (2009), Encyclical Letter Caritas in Veritate, on Integral Human Development in Charity and Truth.

Benedict XVI (2011), Address during the visit to Bundestag in Berlin.

Catechizm of the Catholic Church (1994).

Congregation for the Doctrine of the Faith (1987), Donum Vitae: Instruction on Respect for Human Life in Its Origin and on the Dignity of Procreation.

Congregation for the Doctrine of the Faith (2008), Dignitas Personae: Instruction on Certain Bioethical Questions.

Francis (2015), Encyclical Letter Laudato Si on Care for our Common Home.

John Paul II (1986), The Redemption of the Body and Sacramentality of Marriage (Theology of the Body).

John Paul II (1991), Encyclical Letter Centesimus Annus.

John Paul II (1995), Encyclical Letter Evangelium Vitae, on the Value and Inviolability of Human Life.

Paul VI (1968), Encyclical Letter Humanae vitae, on the Regulation of Birth.

\section{Source literature}

Augustyn J. (1995), Integracja seksualna. Przewodnik w poznawaniu i kształtowaniu własnej seksualności, Kraków.

Bartoszek A. (2014), Moralne aspekty stosowania środków antykoncepcyjnych (z uwzględnieniem sytuacji szczególnych), in: Rodzina miłościq wielka (?), ed. W. Surmiak, Katowice, p. 226-245.

Brusiło J. (2016), Arka Noego jako teologicznomoralny archetyp zmagań człowieka z przyroda i zmianami klimatycznymi, "Teologia i Moralność" 11(1), p. 29-45.

Ejtminowicz N., Urban K., Zięba A. ed. (2016) Ekologia prokreacji, Kraków.

Fijałkowski W. (2001), Ekologia rodziny, Kraków.

Gadzinowski J. (2017), Poczęcie naturalne, in vitro i 'NaPro, “Teologia i Moralność" 12(2), p. 127 -139 . 
Grzelak S. (2006), Profilaktyka ryzykownych zachowań seksualnych młodzieży. Aktualny stan badań na świecie $i$ w Polsce, Warszawa.

Jurczyk B. (2016), Bezdroża ekologii - chrześcijańska krytyka wspótczesnych nurtów ekologii, "Teologia i Moralność" 11(1), p. 17-28.

Kopera E. (2010), NaProTechnology - ekologia kobiecego cyklu, “Życie i Płodność” 4(2), p. 89-93. Marcol A. (1998), Etyka życia seksualnego, Opole.

Piacenza M.(2019), https://ekai.pl/kard-piacenza-spowiedz-jedyna-ekologia-duszy/ [accessed: 14.07. 2019].

Szafulski A. (2016), Ekologiczna perspektywa we współczesnym nauczaniu Magisterium, "Teologia i Moralność" 11(1), p. 47-58.

Wojtyla K. (1993), Love and Responsibility, translated by H.T. Willetts, San Francisco

Wyrostkiewicz M. (2016), Ekologia ludzka jako poszerzona perspektywa ekologiczna, "Teologia i Moralność" 11 (1), p. 59-69.

Antoni BartoszeK - prezbiter archidiecezji katowickiej, teolog moralista; profesor Uniwersytetu Śląskiego, dziekan Wydziału Teologicznego; równocześnie kapelan w Ośrodku dla Niepełnosprawnych w Rudzie Śląskiej. Autor i redaktor kilku książek naukowych, autor kilkudziesięciu artykułów naukowych z teologii moralnej społecznej, bioetyki, etyki seksualnej, nauk o rodzinie. 